JOURNAL OF INFORMATICS AND TELECOMMUNICATION ENGINEERING

Available online http://ojs.uma.ac.id/index.php/jite

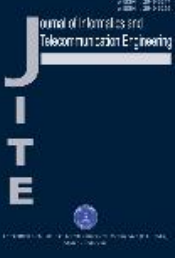

\title{
Sistem Pendeteksian Manusia untuk Keamanan Ruangan menggunakan Viola - Jones
}

\section{Human Detection System For Room Security Using Viola - Jones}

\author{
Jonatan Sianturi*, Romi Fadillah Rahmat, Erna Budhiarti Nababan \\ Universitas Sumatera Utara \\ *E-mail Korespondensi : jonatan sianturi@students.usu.ac.id
}

\begin{abstract}
Abstrak
Aspek keamanan sangat dibutuhkan dalam berbagai kehidupan saat ini seperti keamanan rumah, gedung, atau ruangan yang memiliki nilai penting bagi pemilik. Keamanan dapat dikerjakan oleh tenaga manusia tetapi cara ini kurang efisien karena menghabiskan banyak resources seperti uang, waktu, tenaga dan juga sangat rentan terhadap kelalaian manusia (human error). Oleh karena itu diperlukan suatu pendetekatan untuk dapat melakukan keamanan tersebut.Salah satu pendekatan yang dapat dilakukan adalah dengan melakukan pendeteksian objek manusia melalui kamera yang terhubung dengan komputer.Dalam penelitian ini digunakan Viola-Jones untuk mendeteksi objek manusia dalam citra berdasarkan fitur. Citra yang diinput dari webcam dengan fungsi capture dalam library OpenCV diubah menjadi citra abu-abu setelah mengalami proses scaling, dilanjutkan ekualisasi histogram, perhitungan fitur dengan citra integral, dan pendeteksian objek dengan cascade of classifier. Pada penelitian ini ditunjukkan bahwa metode yang diajukan mampu melakukan pendeteksian objek dengan hasil akurasi mencapai $86,88 \%$.
\end{abstract}

Kata Kunci : viola-jones, pendeteksian manusia, keamanan ruangan, cascade of classifier, opencv.

\begin{abstract}
Security aspects are needed in a variety of life today such as home security, building, or a room that has a significant value for the owner. Security can be done by human power, but this method is less efficient because it spends a lot of resources such as money, time, energy and also very prone to human error. Therefore it is necessary to be able to perform a room security. One approach that can be done is to make the detection of human object through a camera connected to the computer. In this thesis Viola-Jones is used to detect human objects in the image based on the features. Inputted image from the webcam using capture function in the OpenCV library is converted to gray image after undergoing a process of scaling, and then the image get histogram equalization process, the calculation of the integral features of the image, and object detection with a cascade of classifier. In this study indicated that the proposed method is able to perform object detection with accuracy result is $86,88 \%$.
\end{abstract}

Keywords : viola-jones, human detection, room security, the cascade of classifier, opencv 


\section{PENDAHULUAN}

Pengolahan citra digital merupakan salah satu subjek dari teknologi informasi yang sangat menarik dan menantang saat ini. Proses pengolahan citra digital bertujuan untuk memanipulasi dan menganalisis citra dengan bantuan komputer. Pengolahan citra digital dapat dikelompokkan ke dalam dua jenis kegiatan yaitu memperbaiki kualitas suatu gambar dan mengolah informasi yang terdapat pada suatu gambar untuk keperluan pengenalan objek secara otomatis.

Pendeteksian manusia merupakan salah satu bidang penelitian dalam pengolahan citra digital yang dapat digunakan untuk berbagai hal. Salah satu manfaat dari pendeteksian manusia adalah keamanan. Aspek keamanan sangat dibutuhkan dalam berbagai kehidupan saat ini seperti keamanan rumah, gedung, atau ruangan yang memiliki nilai penting bagi pemilik. Keamanan dapat dikerjakan oleh tenaga manusia tetapi caraini kurang efisien karena menghabiskan banyak resources seperti uang, waktu, tenaga dan juga sangat rentan terhadap kelalaian manusia (human error).

Ada banyak penelitian yang telah dilakukan tentang pendeteksian manusia baik dalam gambar maupun video yang dalam penelitiannya mendeteksi bagian dari tubuh manusia. Chen dalam penelitiannya menggunakan metode invarian dari ilmunasi dan pose[1] untuk mendeteksi bagian manusia pada gambar statis. Aziz et al menggunakan metode skeleton graph[2] untuk mendeteksi bagian kepala pada objek manusia dimana skeleton graph diekstraksi dari latar depan dengan menggunakan substraksi latar belakang (background substraction) dan Subburaman menggunakan metode interest point detector dan adaboost [3, 4], dimana interest point detector berguna untuk mengurangi lokasi pencarian sehingga pencarian wilayah yang mirip dengan bagian objek lebih cepat dan adabost classifier berfungsi sebagai pendeteksi objek.

Viola-Jones merupakan sebuah metode yang memilki algoritma yang efisien dalam mendeteksi objek. Dalam metode Viola-Jones terdapat empat kontribusi utama yaituhaar-like feature, citra integral, adaboost, dan cascade of classifier. Haar-like feature adalah fitur yang didasarkan pada Wavelet Haar [5] yang digunakan sebagai dasar untuk penentuan objek. Citra integral adalah representasi tengah untuk citra dan terdiri dari jumlah nilai keabu-abuan dari citra $\mathrm{N}$ dengan tinggi $\mathrm{y}$ dan lebar $\mathrm{x}$ dimana nilai tiap pikselnya merupakan akumulatif dari nilai piksel atas dan kirinya yang digunakan untuk pendeteksian fitur secara cepat. Adaboost merupakan sebuah metode boosting yang berfungsi untuk mencari fitur-fitur yang memiliki tingkat pembeda yang tinggi untuk dievaluasi terhadap data latih. Cascade of classifier merupakan sebuah classifier yang telah terlatih dengan ribuan contoh objek yang terdiri dari objek yang positif dan objek yang negatif. Metode Viola-Jones telah banyak digunakan dalam penelitianpenelitian terutama tentang pendeteksian wajah.Beberapa penelitian diantaranya adalah pendeteksian wajah $[5,6]$ dan pendeteksian mata dan mulut [7].

Pada penelitian ini diajukan implementasi Viola-Jones untuk mendeteksi manusia dalam citra yang 
diperoleh dari webcam dimana penulis menggunakan parameter haarcascade_mcs_upperbody.xml dari library OpenCV[8, 9] yang dikhususkan untuk pelacakan bagian bahu dan kepala manusia dengan posisi kemiringan $0^{0}-$ $45^{0}$ dari objek yang ingin dideteksi.

\section{METODE PENELITIAN}

Arsitektur umum dari metode yang diajukan pada penelitian ini dapat dilihat pada Gambar 1. Rangkaian langkah yang diajukan dalam mendeteksi manusia dalam penelitian ini adalah sebagai berikut : inisialisasi kamera yang digunakan sebagai alat untuk pengambilan data; scaling citra dari kamera dengan metode interpolasi; pengubahan citra warna tersebut menjadi citra abu-abu dengan proses grayscaling; proses histrogram equalization citra; pembacaan fitur haar yang diambil dari library OpenCV yaitu haarcascade_mcs_upperbody.xml;

perhitungan fitur dengan citra integral; pendeteksian objek dengan cascade of classifier. Setelah rangkaian langkah diatas maka akan ditampilkan bagian objek yang terdeteksi sebagai manusia atau bukan, dengan memberi tanda bujur sangkar jika objek tersebut dianggap sebagai manusia. Setiap tahapan yang dilakukan akan dijelaskan dengan lebih terperinci pada bagian-bagian selanjutnya.

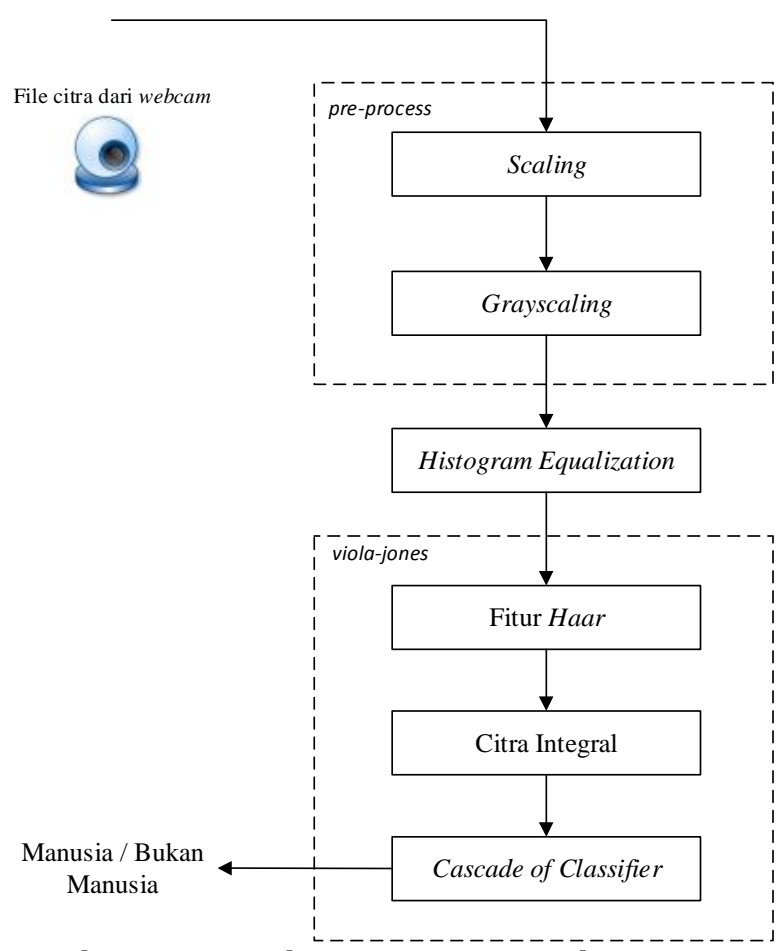

Gambar 1. Arsitektur umum metode yang diajukan

Data yang digunakan dalam penelitian ini adalah citra yang diambil dari kamera secara real-time. Beberapa hal yang diperhatikan pada data yang digunakan yaitu :

a. Pencahayaan

b. Jarak pengambilan gambar

c. Kualitas gambar

Dalam penelitian ini, penulis menggunakan webcam dengan kualitas 2 MP, dalam ruangan dengan cahaya yang terangnya \pm 200 lux, jarak $1-6$ meter dari objek yang akan dideteksi. Hal ini dilakukan agar dapat menangkap objek yang akan dideteksi dengan cukup jelas.

Penjelasan lebih lanjut dari rangkaian langkah pada arsitektur umum metode yang diajukan adalah sebagai berikut: 
Jonatan Sianturi, Romi Fadillah Rahmat, Erna Budhiarti Nababan Sistem Pendeteksian Manusia

\section{Scaling}

Adalah proses mengubah ukuran citra digital sehingga semua citra digital yang dimasukkan memiliki ukuran yang sama dan mengurangi resources yang harus digunakan jika ukuran gambar yang dimasukkan besar. Proses scaling dilakukan dengan menggunakan metode interpolasi. Metode ini menggunakan ratarata suatu daerah untuk mewakili daerah tersebut seperti tampak pada Gambar 2.

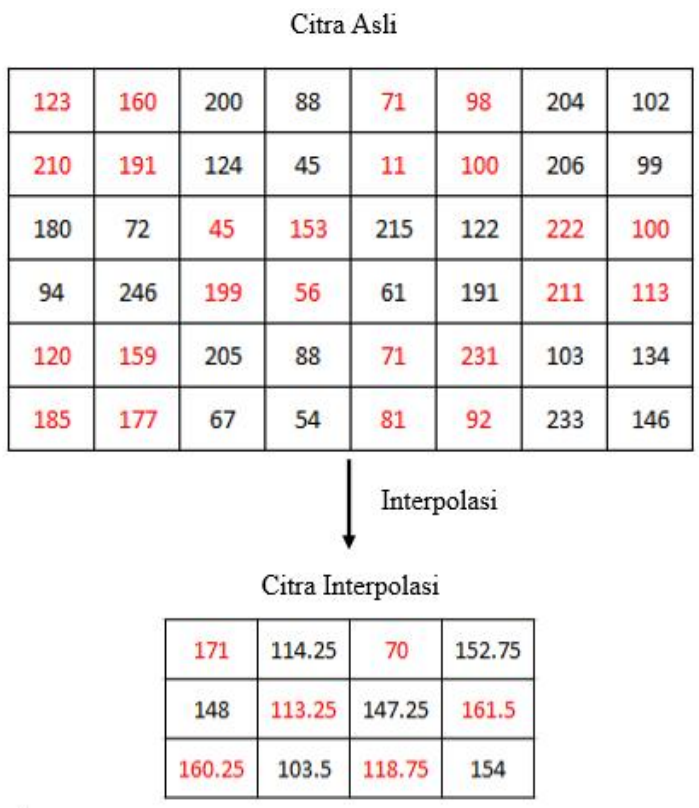

Gambar 2.Metode Interpolasi untuk Memperkecil Gambar

Nilai piksel pada citra hasil interpolasi diperoleh dengan menghitung rata-rata dari empat (4) nilai piksel pada citra asli seperti tampak pada Tabel 1.

Tabel 1. Perhitungan Nilai Piksel Hasil Interpolasi

\begin{tabular}{|c|c|}
\hline Nilai Piksel Citra Asli & $\begin{array}{c}\text { Nilai Piksel Citra Hasil } \\
\text { Interpolasi }\end{array}$ \\
\hline$(123+160+210+191) / 4$ & 171 \\
\hline$(200+88+124+45) / 4$ & 114,25 \\
\hline$(71+98+11+100) / 4$ & 70 \\
\hline$(204+102+206+99) / 4$ & 152,75 \\
\hline$(180+72+94+246) / 4$ & 148 \\
\hline$(45+153+199+56) / 4$ & 113,25 \\
\hline$(215+122+61+191) / 4$ & 147,25 \\
\hline$(222+100+211+113) / 4$ & 161,5 \\
\hline$(120+159+185+177) / 4$ & 160,25 \\
\hline$(205+88+67+54) / 4$ & 103,5 \\
\hline$(71+231+81+92) / 4$ & 118,75 \\
\hline$(103+134+233+146) / 4$ & 154 \\
\hline
\end{tabular}

Contoh hasil scaling dengan metode interpolasi dapat dilihat pada Gambar 3.

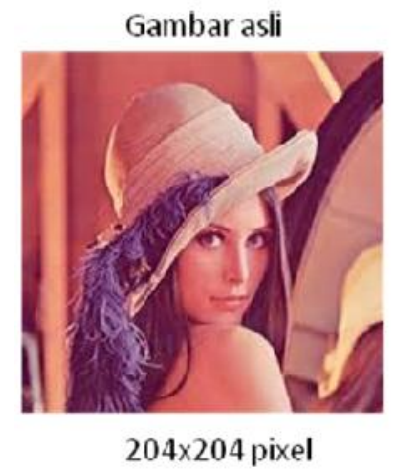

Gambar hasil scaling

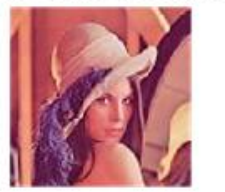

$102 \times 102$ pixel

Gambar 3. Penskalaan Citra dengan Metode Interpolasi [10]

\section{Grayscaling}

Citra yang telah melalui proses scaling kemudian diubah menjadi citra abu-abu. Proses pengubahan citra warna RGB menjadi citra abu-abu dilakukan dengan mengikuti aturan sebagai berikut:

$$
\text { grayscale }=0.299 R+0.587 G+0.114 B
$$

Misalkan sebuah citra memiliki nilai $\mathrm{R}=$ 155, $G=120$, dan $B=135$, maka nilai 
grayscale dari citra tersebut adalah sebagai berikut :

$$
\begin{gathered}
\text { Grnysrale }=\begin{array}{c}
(0,299 \times 155)+(0,587 \times \\
120)+(0,114 \times 135)
\end{array} \\
\text { graysiale }=46,345+70,44+15,39 \\
\text { grayscale }=132,175
\end{gathered}
$$

Contoh citra hasil grayscale dapat dilihat pada Gambar 4.
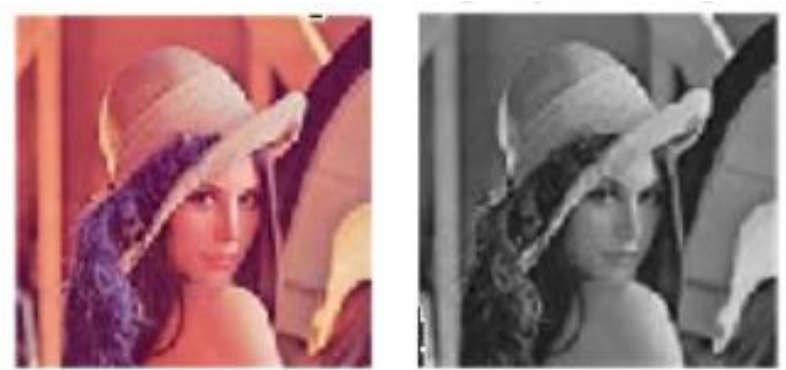

Gambar 4. Grayscaling [10]

\section{Histogram Equalization}

Histogram Equalization adalah suatu proses perataan histogram yaitu perataan distribusi nilai derajat keabuan pada suatu citra digital. Untuk dapat melakukan histrogram equalization diperlukan suatu fungsi distribusi kumulatif yang merupakan kumulatif dari histogram. Misalkan diketahui data citra sebagai berikut :

\section{2}

Proses perhitungan distribusi kumulatif dapat dilihat pada Tabel 2.
Tabel 2. Proses Perhitungan Distribusi Kumulatif

\begin{tabular}{|c|c|c|}
\hline Nilai & Histogram & Distribusi Kumulatif \\
\hline 0 & 1 & 1 \\
\hline 1 & 2 & $1+2=3$ \\
\hline 2 & 2 & $3+2=5$ \\
\hline 3 & 4 & $5+4=9$ \\
\hline 4 & 2 & $9+2=11$ \\
\hline 5 & 0 & $11+0=11$ \\
\hline 6 & 1 & $11+1=12$ \\
\hline
\end{tabular}

Setelah nilai distribusi kumulatif diperoleh, kemudian dilakukan perataan histogram seperti tampak pada Tabel 3.

Tabel 3. Teknik Perhitungan Histrogram

\begin{tabular}{|c|c|c|}
\hline Nilai Asal & Histogram & Nilai Hasil \\
\hline 0 & 1 & $1 / 2 \rightarrow 0$ \\
\hline 1 & 3 & $3 / 2 \rightarrow 1$ \\
\hline 2 & 5 & $5 / 2 \rightarrow 2$ \\
\hline 3 & 9 & $9 / 2 \rightarrow 4$ \\
\hline 4 & 11 & $11 / 2 \rightarrow 5$ \\
\hline 5 & 11 & $11 / 2 \rightarrow 5$ \\
\hline 6 & 12 & $12 / 2 \rightarrow 6$ \\
\hline
\end{tabular}

Hasil setelah proses histrogram equalization adalah :

254146541042

\section{Fitur Haar}

Dalam metode viola-jones, pendeteksian objek dilakukan berdasarkan pada nilai fitur. Penggunan fitur dilakukan karena pemrosesan fitur berlangsung lebih cepat dibandingkan pemrosesan citra per piksel. Pencarian objek manusia dilakukan dengan mencari fitur-fitur yang memiliki tingkat pembeda yang tinggi. Hal ini dilakukan dengan mengevaluasi setiap 
fitur terhadap data latih dengan dan kirinya. Salah satu contoh seperti menggunakan nilai dari fitur tersebut. Pada Gambar 6.

penelitian ini penulis menggunakan haarcascade_mcs_upperbody.xml yang dikhususkan untuk pelacakan bagian bahu dan kepala manusia. Fitur yang memiliki batas terbesar antara manusia dan bukan manusia dianggap sebagai fitur terbaik.

Sebagai contoh, misalnya kita melakukan pencarian wajah manusia dalam citra. Salah satu daerah wajah manusia adalah daerah mata dan pipi. Pada umumnya daerah mata akan berwarna lebih gelap sedangkan daerah pipi akan berwarna lebih terang seperti pada Gambar 5.

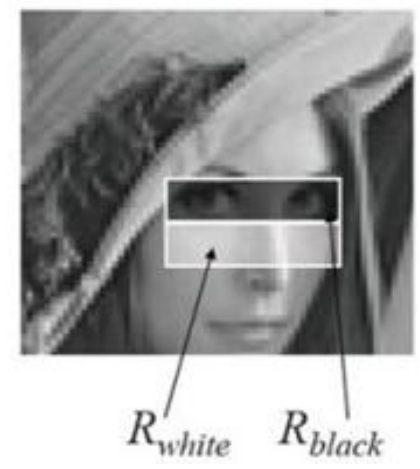

Gambar 5. Pencarian Fitur Haar

Perhitungan nilai haar mengikuti aturan sebagai berikut :

$$
F_{\text {Hoar }}=\sum R_{\text {black }} \sum R_{\text {white }}
$$

\section{Citra Integral}

Citra integral adalah representasi tengah untuk citra dan terdiri dari jumlah nilai keabu-abuan dari citra $N$ dengan tinggi y dan lebar $\mathrm{x}$ dimana nilai tiap pikselnya merupakan akumulatif dari nilai piksel atas

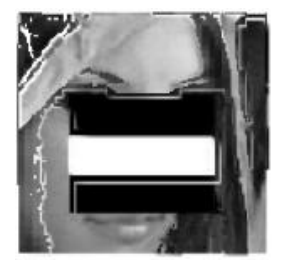

Gambar 6. Contoh Perhitungan Citra Integral [10]

Misalkan nilai abu-abu dalam kotak haar tersebut seperti Gambar 7.

\begin{tabular}{|l|l|l|}
\hline 1 & 2 & 3 \\
\hline 4 & 5 & 6 \\
\hline 7 & 8 & 9 \\
\hline
\end{tabular}

Gambar 7. Nilai Grayscale Citra Masukkan

Perhitungan citra integral dari nilai abuabu dalam Gambar 7 dapat dilihat pada Gambar 8.

\begin{tabular}{|l|l|l|}
\hline 1 & $1+2$ & $1+2+3$ \\
\hline $1+4$ & $1+2+4+5$ & $1+2+3+4+5+6$ \\
\hline $1+4+7$ & $1+2+4+5+7+8$ & $1+2+3+4+5+6+7+8+9$ \\
\hline
\end{tabular}

Gambar 8. Perhitungan Citra Integral

Maka diperoleh hasil perhitungan citra integralnya seperti Gambar 9.

\begin{tabular}{|c|c|c|}
\hline 1 & 3 & 6 \\
\hline 5 & 12 & 21 \\
\hline 12 & 27 & 45 \\
\hline
\end{tabular}

Gambar 9. Hasil Citra Integral 


$$
\begin{aligned}
& \text { Nilai fitur }=\mid \begin{array}{l}
\mid(\text { total piksel hitam })-(\text { total } \\
\text { piksel putih }) \mid
\end{array} \\
& =\mid\{[(6+0)-(0+0)]+[(45+0)-(21+0)]\} \\
& \quad-[(21+0)-(6+0)] \mid \\
& =|6+24-15| \\
& =15
\end{aligned}
$$

Nilai fitur yang diperoleh merupakan nilai perbedaan antara kotak putih dan hitam yang biasa disebut dengan treshold. Nilai inilah yang digunakan sebagai parameter klasifikasi objek yang terdeteksi sebagai manusia (wajah) atau bukan.

\section{Cascade of Classifier}

Cascade of Classifier merupakan suatu metode pengklasifikasian bertingkat dimana masukan dari setiap tingkatan merupakan keluaran dari tingkat sebelumnya yang telah dibentuk dari hasil machine learning Adaboost. Bentuk dari cascade of classifier dapat dilihat pada Gambar 10.

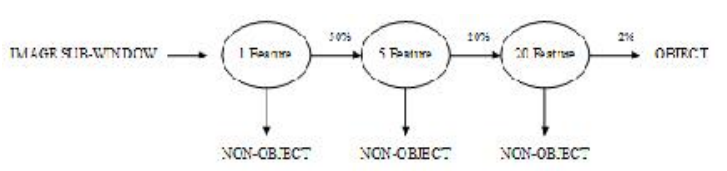

Gambar 10. Alur Kerja Klasifikasi Bertingkat

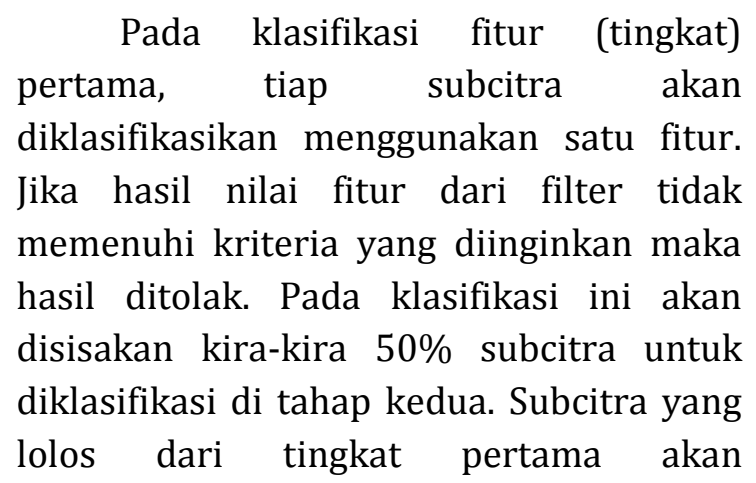

diklasifikasikan lagi pada tahap kedua dimana pada tahap kedua jumlah fitur yang digunakan lebih banyak. Semakin bertambah tingkat klasifikasi maka fitur yang digunakan semakin banyak. Jumlah subcitra yang lolos dari klasifikasi pun akan berkurang hingga mencapai $2 \%$. Subcitra yang berhasil melewati semua tingkat klasifikasi akan dinyatakan sebagai manusia (objek yang dideteksi). Salah satu contoh dari hasil filer pada proses cascade of classifier dapat dilihat pada Gambar 11.

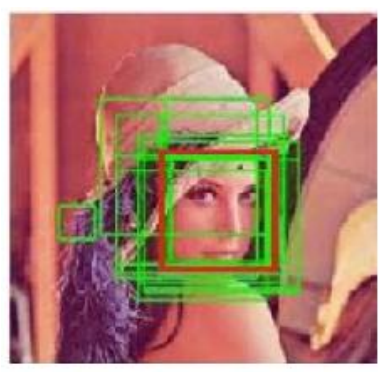

Gambar 11. Hasil Deteksi Wajah [10]

\section{HASIL DAN PEMBAHASAN}

\section{Perancangan Sistem}

Rancangan sistem yang dibangun dalam penelitian ini adalah tampak seperti flowchart pada Gambar 12. 


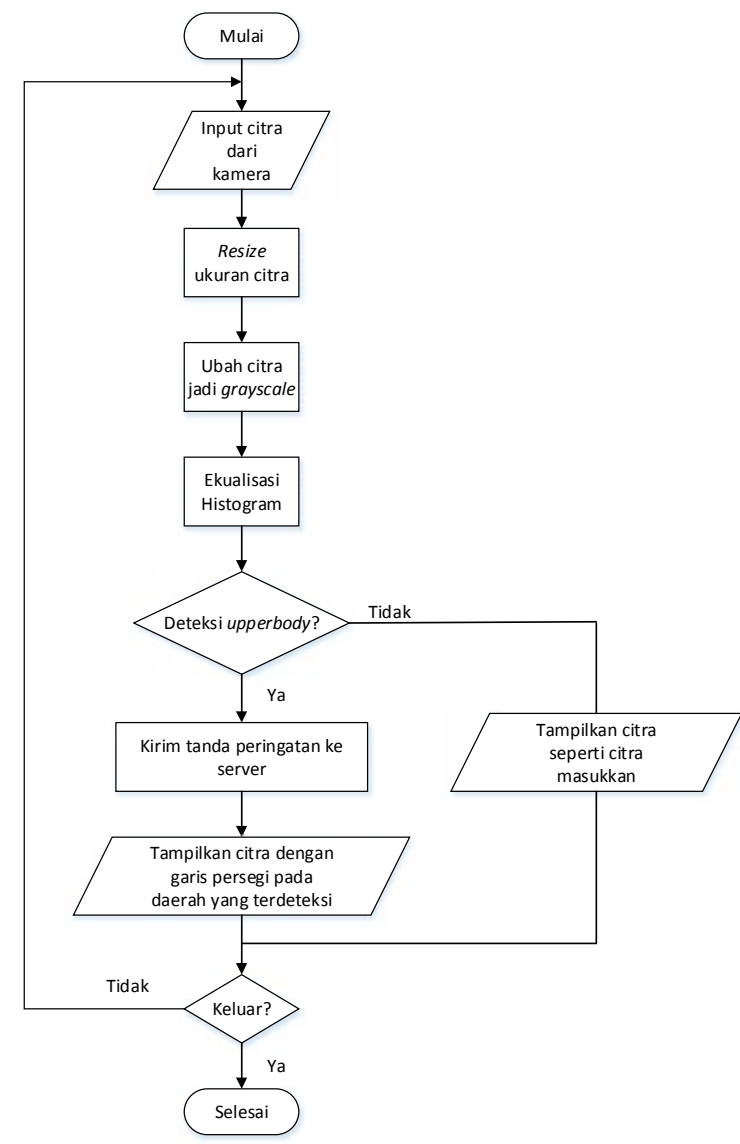

Gambar 12. Flowchart Sistem Pendeteksian Manusia

Rancangan jaringan yang dibangun dalam sistem ini dapat dilihat pada Gambar 13.

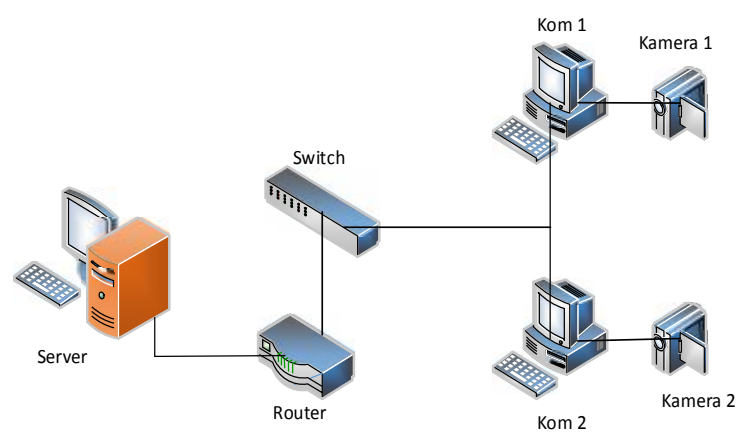

Gambar 13. Rancangan Jaringan Sistem

Pendeteksian Manusia untuk Keamanan

Ruangan
Adapun penjelasan dari Gambar 13 adalah sebagai berikut :

- Setiap komputer yang terhubung ke server akan melakukan proses pendeteksian manusia sepert flowchart yang tampak pada Gambar 12 dengan menggunakan kamera yang masingmasing terhubung ke komputer tersebut.

- Jika ada objek yang terdeteksi sebagai manusia, maka setiap komputer akan mengirimkan pesan bahwa ada objek manusia yang terdeteksi, ip, dan nama komputer tersebut.

- Saat server menerima pesan dari komputer tersebut, server akan membunyikan suara peringatan (warning) bahwa ada objek yang terdeteksi dan mencetak ip dan nama komputer tersebut.

Pengujian sistem dilakukan untuk memeriksa kinerjaantar komponen sistem yang diimplementasikan. Tujuan utama dari pengujian sistem adalah untuk memastikan bahwa elemen-elemen atau komponen-komponen dari sistem telah berfungsi sesuai dengan yang diharapkan. Parameter pengujian yang digunakan dalam penelitian ini meliputi:

1. Waktu pendeteksian, disajikan dalam satuan miliseconds (ms).

2. Keakuratan pendeteksian, disajikan dalam bentuk persentase. 


\section{Waktu Pendeteksian}

Hasil waktu pengujian dengan kamera web (resolusi gambar 480 x 320) dapat dilihat pada Tabel 4.

Tabel 4. Hasi Pengujian Waktu Pendeteksian

\begin{tabular}{|l|l|l|}
\hline No. & \multicolumn{1}{|c|}{$\begin{array}{c}\text { Nama } \\
\text { Frame }\end{array}$} & \multicolumn{1}{|c|}{ Waktu } \\
Pendeteksian $(\mathbf{m s})$
\end{tabular}

Dari pengujian yang dilakukan terhadap 20 frame, diperoleh rata-rata waktu pendeteksian sebagai berikut:

\section{Rata-rata waktu =}

Total waktu pendeteksian Jumlah datc

$$
\begin{aligned}
& =\frac{2531,54}{20} \\
& =126,58 \mathrm{~ms}
\end{aligned}
$$

Waktu pendeteksian tercepat adalah $116,59 \mathrm{~ms}$.

Waktu pendeteksian terlama adalah 146,11 ms.

\section{Keakuratan Pendeteksian}

$$
\text { Untuk menghitung keakuratan }
$$
pendeteksian digunakan rumus berikut :

$$
\text { Keakuratan pendeteksian }(\%)=\frac{A+B}{2}
$$

\begin{tabular}{|c|c|}
\hline true_positive & $\begin{aligned}= & \text { jumlah objek } \\
& \text { terdeteksi } \\
& \text { yang benar }\end{aligned}$ \\
\hline $\begin{array}{l}\text { human_on_image } \\
\text { dalam citra }\end{array}$ & $=$ jumlah manusia \\
\hline human_detected & $\begin{aligned}= & \text { jumlah seluruh } \\
& \text { objek yang } \\
& \text { terdeteksi } \\
& \text { (true_positive + } \\
& \text { false_positive). }\end{aligned}$ \\
\hline
\end{tabular}

Dengan :

$$
\begin{aligned}
& \Lambda-\frac{\text { true_positve }}{\text { human_on_image }} \\
& B=\frac{\text { true_positve }}{\text { human_detected }}
\end{aligned}
$$

\section{Dimana :}

Dalam penelitian ini penulis melakukan pengujian sistem pada beberapa ruangan dengan keadaan cahaya, kemiringan kamera, dan jumlah objek yang berbedabeda, serta objek yang bukan manusia. Hasil pendeteksian yang benar dapat pada Gambar 14 bagian (a), (b), (c), (d), dan (e). 


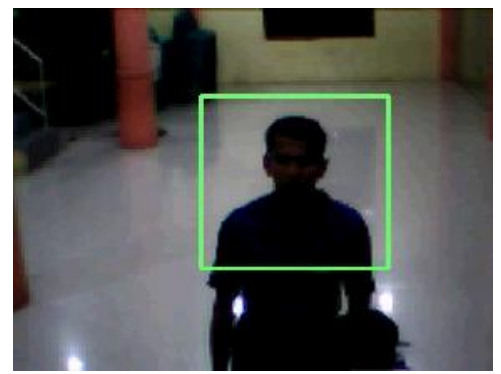

(a) Ruangan A

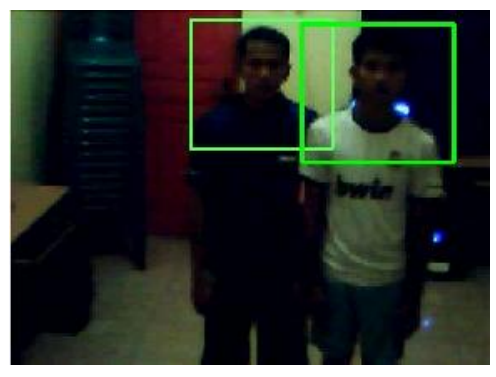

(b) Ruangan B

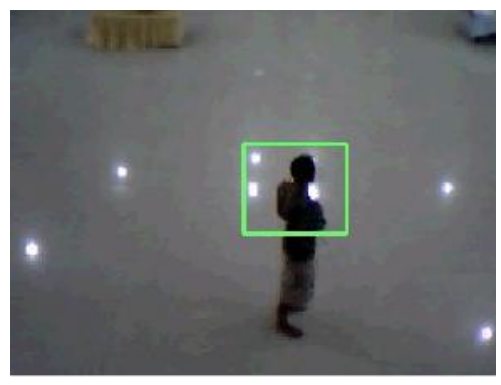

(c) Ruangan C

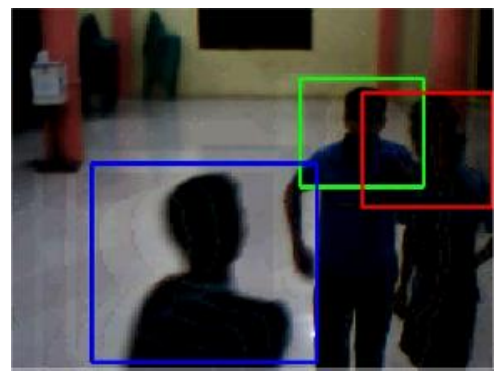

(d) Ruangan D

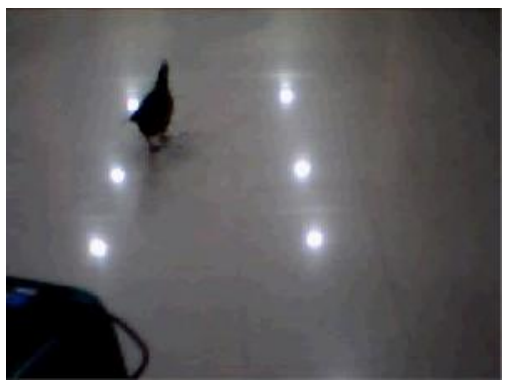

(e) Ruangan E : pengujian dengan objek ayam

Dalam pengujian terdapat juga hasil pendeteksian yang salah atau objek yang tidak terdeteksi seperti tampak pada Gambar 15 bagian (a), (b), (c), dan (d).

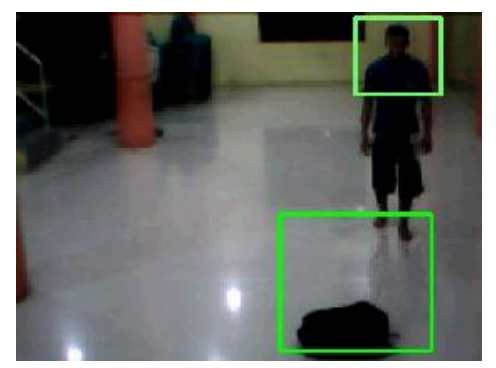

(a) Ruangan A : terdeteksi 2 objek

(1 benar dan 1 salah)

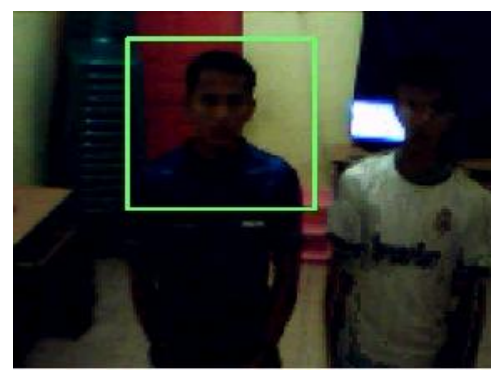

(b) Ruangan B : terdeteksi 1 objek

(objek dalam citra ada 2) 


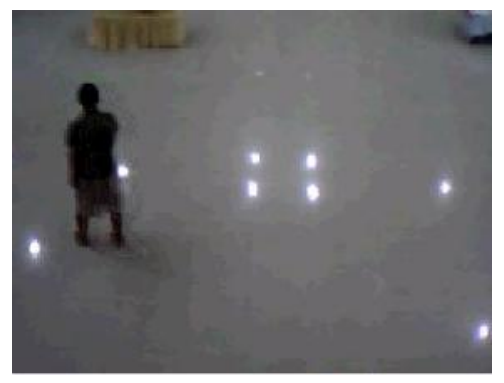

(c) Ruangan C : objek tidak terdeteksi

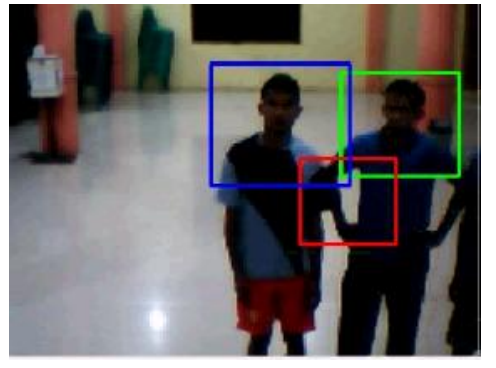

(d) Ruangan D : terdeteksi 3 objek

( 2 benar dan 1 salah)

Dari hasil pengujian pada Ruangan A, B, C, dan D, maka diperoleh akurasi pendeteksian sebagai berikut :

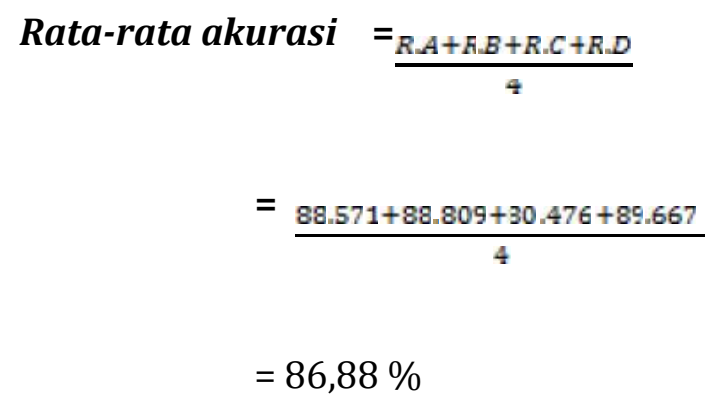

\section{SIMPULAN}

Berdasarkan pengujian sistem pendeteksian manusia untuk keamanan ruangan dengan metode viola-jones didapat beberapa kesimpulan yaitu:

1. Waktu pendeteksian tercepat yang diperoleh adalah 116,59 ms dan waktu pendeteksian terlama yang diperoleh adalah 146,11 ms.
2. Akurasi pendeteksian yang diperoleh mencapai 86,88\%.

3. Cahaya ruangan, posisi kamera, dan posisi objek sangat mempengaruhi hasil pendeteksian.

4. Citra integral berguna mempercepat proses perhitungan haar like feature karena hanya perlu melakukan perhitungan pada empat buah titik piksel pada setiap persegi haar like feature.

5. Cascaded classifier memberikan kontribusinya dengan mempercepat proses pendeteksian yaitu dengan menolak langsung semua citra sub-window yang tidak memenuhi salah satu classifier.

Pada penelitian selanjutnya dapat menerapkan metode Viola-Jones untuk membuat sistem penghitung jumlah orang (people counter) dengan menambahkan metode tracking untuk mengikuti objek tersebut.

\section{DAFTAR PUSTAKA}

Aziz, K., Merad, D., Fertil, B. dan Thome, N. 2011. Pedestrian Head Detection and Tracking Using Skeleton Graph for People Counting in Crowded Environments. 2th IAPR Conference on Machine Vision Application : 516-519.

Bradski, G dan Kaehler, A. 2008. Learning OpenCV. O'Relly Media, Inc : Sebastopol.

Castrillón, S. M., Déniz, O., Guerra, C., dan Hernández, M. 2007. ENCARA2 : Real-time Detection of Multiple Faces at Different Resolutions in Video Streams. Journal of Visual Communication and Image Representation 18 (2):130-140.

Santoso, H dan Harjoko, A. 2013. Haar

Cascade Classifier dan Algoritma Adaboost untuk Deteksi Banyak Wajah dalam Ruang Kelas. Jurnal Teknologi 6 (2):108-115.

Chen, M., Ma, G., Kee. dan Kee, S. 2005. Multi-view Human Head Detection in Static Images. Conference on Machine Vision Applications 3(21):100-103. 
Jonatan Sianturi, Romi Fadillah Rahmat, Erna Budhiarti Nababan Sistem Pendeteksian Manusia

Khan, I., Abdullah, H. dan Zainal, M, S, B. 2012.

Efficient Eyes and Mouth Detection Algortihm using Combination of Viola Jones and Skin Color Pixel Detection. International Journal of Engineering and Applied Sciences 3 (4):51-60.

Subburaman, V. B. 2012. Alternative Search Techniques for Face Detection Using Location Estimation and Binary Features. Tesis. Politeknik Federal Lausanne.

Subburaman, V. B., Descamps, A. dan Carincotte, C. 2012. Counting People in the Crowd Using a Generic Head Detector. Advanced Video and Signal-Based Surveillance : 470-475p.

Viola, P dan Jones, M. 2001. Rapid Object Detection using a Boosted Cascade of Simple Features. Proceedings IEEE Conf. on Computer Vision and Pattern Recognition 1:511-518.

Viola, P dan Jones, M. 2004. Robust Real-Time Detection. International Journal of Computer Vision 57(2):137-154. 